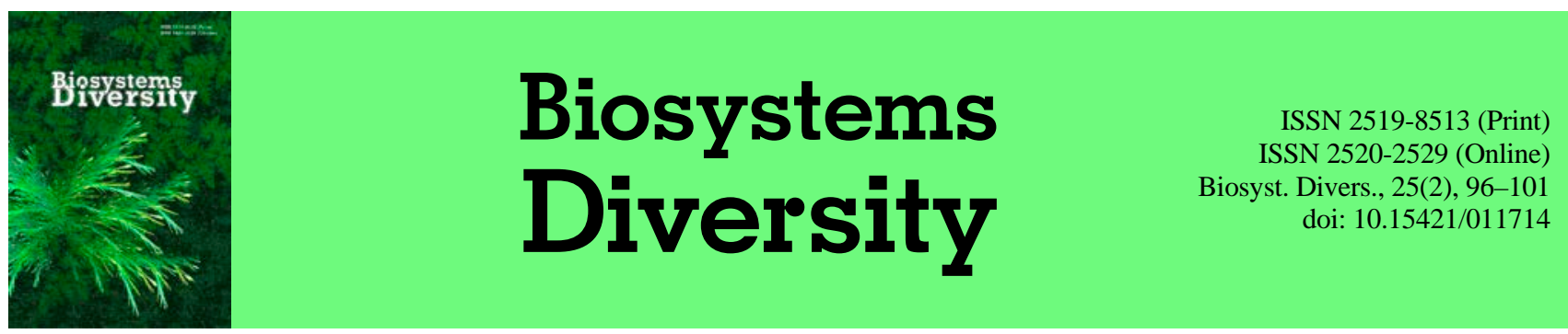

\title{
Morphometric characteristics and the content of plastid pigments of the needles of Picea pungens depending on the distance from the highways
}

\author{
V. P. Bessonova, O. A. Ponomaryova \\ Dnipro State Agrarian-Economic University, Dnipro, Ukraine
}

\section{Article info}

Received 24.04.2017

Received in revised form 14.05.2017

Accepted 15.05.2017

Dnipro State Agrarian-Economic University, Sergiy Efremov Str. 25, Dnipro, 49600, Ukraine. Tel.: +38-097-871-99-70 E-mail: lponomareva@i.ua

\begin{abstract}
Bessonova, V. P., \& Ponomaryova, O. A. (2017). Morphometric characteristics and the content of plastid pigments of the needles of Picea pungens depending on the distance from the highways. Biosystems Diversity, 25(2), 96-101. doi:10.15421/011714
\end{abstract}

This article examines the condition of the Picea pungens Engelm. plants at various distances from urban highways with high traffic intensity. The objects of the study were the trees of $P$. pungens, whose age was about 35 years. The plants grow on four plots. The control plot is located in the conditionally clean zone; the plot $1-120 \mathrm{~m}$ from the road, plot 2 - at a distance of $10 \mathrm{~m}$ and plot 3 - on the median dividing strip of the road. It is established that in plants growing at a distance of $120 \mathrm{~m}$ from the highway and in the control plot, there was no difference in the parameters of the annual growth of shoots. In plants growing at a distance of $10 \mathrm{~m}$ from the road, a decrease in the length and mass of the shoot was determined. In the immediate vicinity of the motorway (on the median strip of the road), the growth rates of shoots decreased most significantly. A similar pattern was observed in the effect of distance from the road on the number of needles per unit length of shoot. The highest amount of chlorophyll $a$ in the needles of spruce, regardless of the variant, was found in May, later it decreased in the summer months, and then increased slightly in September in all variants of the experiment. A similar pattern is also characteristic of changes in the chlorophyll content. The concentration of chlorophyll $a$ in the needles of trees growing at a distance of $120 \mathrm{~m}$ from the highway, almost did not differ from plants in the clean zone. At a distance of $10 \mathrm{~m}$ its content was less, and for plants growing on the median strip of the highway, the amount of this form of green pigment decreased by $35 \%$ of the reference values. The content of chlorophyll $b$, like $a$, is not statistically different in the needles of the trees in the control plot and in plot 1 . In plants of plots 2 and 3 its concentration decreased with respect to control. The sum of the green pigments $a+b$ was the same in the needles of the control plot plants and those $120 \mathrm{~m}$ from the road. In the experimental plots 2 and 3 the amount of chlorophyll $a+b$ in the needles of the $P$. pungens was smaller than in the control and in plot 1 . Depending on the sampling month, the difference with the control ranged from $14.7 \%$ to $21.0 \%$. The content of carotenoids in the needles was spiny, low in plants at a distance of $120 \mathrm{~m}$ from the road, and the highest in specimens that growing in the immediate vicinity of the road.

Keywords: spruce; carotenoids; chlorophyll; needles; roadside plantations

\section{Морфометричні показники та вміст пластидних пігментів хвої Picea pungens залежно від відстані до автошляху}

\author{
В. П. Бессонова, О. А. Пономарьова
}

\section{Дніпровський державний аграрно-економічний університет, Дніпро, Украӥна}

Досліджено стан рослин Picea pungens Engelm. при зростанні на різних відстанях від міської магістралі 3 високою інтенсивністю автомобільного руху. У рослин, які зростають на відстані 120 м від шосе і контрольних дерев, різниці річного прирісту пагонів не виявлено. У рослин, що зростають на відстані 10 м від дороги, визначене зменшення довжини та маси пагона; значення товщини пагона стосовно контролю статистично достовірно не змінюється. У безпосередній близькості до автошляху (на розподільній смузі траси) ростові показники пагонів зменшуються найсуттєвіше. Подібна закономірність спостерігається і за впливом відстані від автодороги на кількість хвоїнок на одиницю довжини пагона. Найвища кількість хлорофілу а у хвої ялини колючої (незалежно від варіанту) виявлена у травні, надалі вона знижується в літні місяці, а потім дещо зростає у вересні в усіх варіантах досліду. Подібна закономірність характерна і для змін вмісту хлорофілу $b$. Концентрація хлорофілу $a$ у хвоїнках дерев, що зростають на відстані 120 м від автошляху, майже така сама, як і у відносно чистій зоні. На віддаленні 10 м його вміст менший. В органах асиміляції рослин розподільної смуги автодороги кількість цієї форми зеленого пігменту зменшується суттєвіше, в середньому на $35 \%$ відносно контрольних значень. Вміст хлорофілу $b$, як і $a$, статистично не відрізняється в хвої дерев на контрольній ділянці та ділянці 1 (120 м до дороги). У рослин, що зростають на відстані 10 м від дороги, його концентрація також змінюється стосовно контролю, але у вересні різниця недостовірна. На розподільній смузі вміст хлорофілу $b$ нижчий, ніж на інших ділянках. Сума зелених пігментів $a+b$ однакова у хвої рослин контрольної ділянки та на відстані 120 м від автошляху. На відстані 10 м від автошляху кількість хлорофілу $a+b$ у хвої дерев ялини менша, ніж у контролі та на ділянці 1 . Залежно від місяця взяття проб різниця з контролем коливається в межах 15-21\%. Більше екологічне навантаження (ділянка 3) викликає суттєвіші зміни вмісту зелених пігментів у хвої. Вміст каротиноїдів у хвої ялини колючої також залежить від віддалення дерев відносно автошляху. 
Найнижчий він у рослин на відстані 120 м, а найвищий - в особин, що зростають у безпосередній близькості від автошляху. Концентрація жовтих пігментів у хвої рослин ділянки 2 становить 118-129\% у різні строки дослідження відносно контролю, на ділянці 3 - 130-150\%. Підвищення концентрації каротиноїдів у хвої рослин, що зростають на відстані 10 м і, особливо, на розподільній зоні автошляху порівняно 3 контролем і ділянкою 1 можна розглядати як адаптивну реакцію, спрямовану на підтримання відносної стабільності фотосинтетичного апарату. Таким чином, зростання дерев ялини колючої на розподільній смузі автошляху негативно впливає на річний приріст пагонів, морфометричні показники хвоїнок стосовно контролю, але їх кількість на 10 см пагона перевищує відповідний показник на інших ділянках. На відстані 120 м від дорожнього полотна показники практично не змінюються стосовно контролю. За суттєвішого забруднення довкілля полікомпонентними викидами автотранспорту (ділянка 2 і 3) вміст хлорофілів $a$ і $b$ у хвої менший, каротиноїдів - навпаки, більший. Концентрація пластидних пігментів на відстані 10 м від автошляху змінюється стосовно контролю, але значно менша, ніж на розподільній смузі. Це свідчить про те, що за сильного стресу хвоя проявляє чутливість до негативного впливу викидів автомобілів, але зі збільшенням відстані від магістралі цей вплив суттєво ослаблюється.

\section{Ключові слова: ялина колюча; каротиноїди; хлорофіл; приріст пагонів; придорожні насадження}

\section{Вступ}

Деревні рослини зеленого пояса міста не тільки зменшують забруднення повітря, а й мають естетичне значення. Тому важливо вивчити реакцію на забруднення повітря уздовж автотрас, що дозволить дати рекомендації відносно майбутнього розвитку зелених поясів у міських районах (Peng-qian Zhang et al., 2016). В озелененні міст важливе місце посідають голонасінні, які цінуються не тільки за декоративні якості, а і за високі санітарно-гігієнічні властивості. Контрастні за формою та забарвленням крони вічнозелених хвойних чітко виділяються серед листопадних порід, особливо взимку, надаючи привабливості зимовому пейзажу. Хвойним рослинам належить велика роль у формуванні архітектурно-художнього вигляду міста. Вони створюють його індивідуальність, підвищують художню виразність міської забудови.

В озелененні міст південного сходу України ще недостатньо використовують хвойні рослини (Brygadyrenko, 2014, 2016), зокрема представників роду Picea L. Особливої уваги заслуговує ялина колюча (Picea pungens Engelm.), яка характеризується багатством внутрішньовидових форм за забарвленням хвої: блакитнозелена (P. pungens Engelm. glauca Reg.), синя (f. coerulea Beissn), срібляста (f. argentea Rosenthalf), золотиста (f. aurea Nielmetz), світло-жовта (f. flavescens Nielmetz), золотисто-пістрява (f. aureovariegata Roz.). Дерева цього виду різні за формою крони: пірамідальні, колоноподібні, плакучі (Kolesnikov, 1974). Тому використання ялини колючої в озелененні заслуговує на увагу. До того ж ця рослина характеризується високою зимо- та морозостійкістю, тіньовитривалістю (Antipov, 2000).

Стосовно рівня стійкості дерев цього виду до забруднювачів довкілля існують деякі розходження. Getko (1989) відносить ялину колючу до першої категорії видів, які можуть бути широко використані в озелененні промислового міста в цілому, тобто в садово-парковому будівництві, для озеленення вулиць і житлових кварталів, але не промислових територій; Il'kun (1978) - до стійких видів, a Sergijchik (1997) - до третьої категорії, яку складають рослини, масове застосування яких в озелененні обмежене. Ці автори дають загальні шкали стійкості до комплексу полютантів, не спираючись на морфо-фізіологічні показники. Високий рівень життєвості ялини колючої за фізіологічними показниками у міських насадженнях м. Іжевськ відмічає низка авторів (Buharina and Povarnitsina, 2008; Buharina and Pashkova, 2015). Суперечливість у висновках науковців стосовно рівня стійкості рослин цього виду пояснюється несхожими кліматичними умовами в місцях проведення досліджень, характером забруднення повітря та грунту та інших негативних чинників міського середовища, що може суттєво впливати на чутливість до забруднювачів.

Мета даного дослідження - проаналізувати вплив різної віддаленості місця зростання від автошляху на морфометричні параметри річного пагона та дворічної хвої ялини колючої та вміст у ній фотосинтетичних пігментів.

\section{Матеріал і методи досліджень}

Як об'єкт дослідження використано дерева ялини колючої (Picea pungens Engelm.), віком близько 30 років, висотою 10-
12 м, діаметром 40-50 см. Кількість модельних дерев - по 5 на кожній ділянці. Рослини зростають на чотирьох ділянках. Контрольна ділянка розташована в умовно-чистій зоні (контроль); ділянка 1 - на відстані 120 м від автошляху; ділянка 2 на відстані 10 м і ділянка 3 - на розподільній смузі автошляху (середня відстань дерев від проїжджої частини 1,5 м). Всі ділянки розташовані на значному віддаленні від промислових джерел забруднення (не менше 10 км), мають однакові грунтові умови, а також рівень інсоляції. Проби відбирали на висоті 2 м із південно-східної частини крони. Морфометричні показники досліджували за загальноприйнятими методиками (Kleyn and Kleyn, 1974). Пігменти екстрагували 100\% ацетоном, розрахунки їх вмісту вели за формулами Vettshtein (Bessonova, 2006). Різницю між значеннями морфометричних і біохімічних показників вважали достовірною за $\mathrm{P}<0,05$.

\section{Результати та їх обговорення}

На ріст пагонів достовірно впливають умови зростання рослин на розподільній смузі шосе та, меншою мірою, на відстані 10 м від нього. Ступінь гальмування цього процесу стосовно контролю - 27,7\% та $16,1 \%$, відповідно. Різниці у довжині річного приросту рослин на відстані 120 м і контрольної ділянки не виявлено. Товщина пагонів зменшується стосовно контрольних значень тільки на третій ділянці (1,5 м від автошляху). Проте маса річного пагона достовірно менша у рослин на відстані 1,5 і 10 м стосовно двох інших ділянок. Відмінність становить $14,1 \%$ та $22,2 \%$ відносно цього показника в контролі (табл. 1, рис. 1). Отже, у рослин, що зростають на відстані 120 м від шосе та контролі різниці параметрів, які характеризують річний приріст пагонів, не виявлено. На відстані 10 м визначене зменшення довжини та маси пагона, значення його товщини стосовно контролю статистично достовірно не змінюється. У безпосередній близькості до автошляху ростові показники пагонів зменшуються найсуттєвіше. Протилежна закономірність спостерігається щодо впливу відстані від автодороги на кількість хвоїнок на одиницю довжини пагона. Їх число на 10 см пагона в контролі і на ділянках 1, 2, 3 складає 190, 200, 222 і 225 шт., що можна пояснити вкороченням міжвузлів.

\section{Таблиця 1}

Вплив відстані від автошляху

на параметри річного пагона ялини колючої

\begin{tabular}{lccc}
\hline \multicolumn{1}{c}{ Ділянка } & Довжина пагонів, см & Товщина пагонів, см & Маса пагона, г \\
\hline Контроль & $10,6 \pm 0,60$ & $4,7 \pm 0,25$ & $59,2 \pm 0,80$ \\
120 м & $10,2 \pm 0,46$ & $4,5 \pm 0,20$ & $58,1 \pm 1,14$ \\
10 м & $8,9 \pm 0,35^{*}$ & $4,4 \pm 0,19$ & $50,9 \pm 1,20^{*}$ \\
1,5 м & $7,8 \pm 0,32^{*}$ & $3,2 \pm 0,31^{*}$ & $40,2 \pm 0,56^{*}$ \\
\hline
\end{tabular}

Примітки: * - різниця між контрольним і дослідним варіантами статистично достовірна за $\mathrm{P}<0,05$; $\mathrm{n}=30$; оцінювання ступеня достовірності проводили за допомогою критерію Стьюдента.

Як видно з таблиці 2, довжина хвої рослин на роздільній смузі автошляху становить 74,5\%, на відстані 10 м - 89,2\% від контролю. У дерев, що зростають на віддаленні 120 м від дороги довжина хвої майже така сама, як в умовно чистій зоні. Подібний вплив умов зростання виявлено і на інші показники хвоїнок - їх сиру масу та площу. Як видно 3 таблиці 2, ці 
показники на ділянках 2 і 3 менші, ніж у контрольних рослин. Відомо, що площа листка - ознака ксероморфності (Lawlor and Tezara, 2009). Ксероморфна будова сприяє підвищенню стійкості рослин за умов забруднення. Набуття рис ксероморфності листками під час зростання в несприятливих умовах спостерігалось і на прикладі інших рослин (Nikolaevskij, 1979; Wannaz et al., 2003).

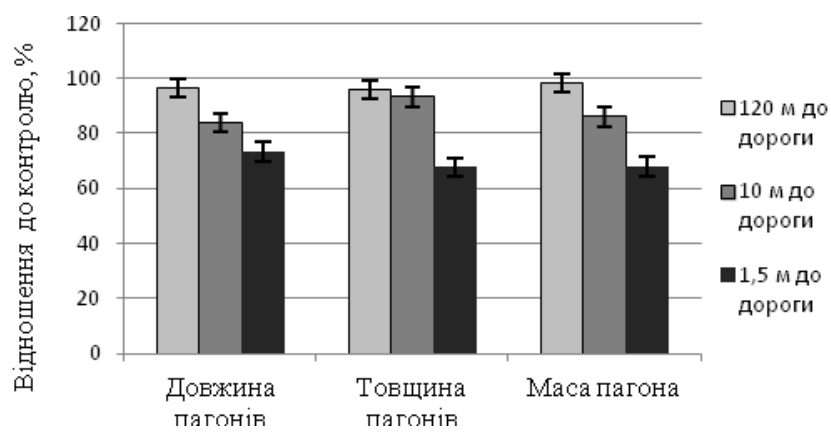

Рис. 1. Зміни приросту ялини колючої при погіршенні умов зростання (\% до контролю)

Таблиця 2

Вплив відстані від автошляху

на показники дворічної хвої ялини колючої

\begin{tabular}{lcccc}
\hline \multicolumn{1}{c}{ Ділянка } & $\begin{array}{c}\text { Довжина } \\
\text { хвоїнки, мм }\end{array}$ & $\begin{array}{c}\text { Ширина } \\
\text { хвоїнки, мм }\end{array}$ & $\begin{array}{c}\text { Площа } \\
\text { хвоїнки, мм }\end{array}$ & $\begin{array}{c}\text { Сира маса } \\
\text { хвоїнок, мг }\end{array}$ \\
\hline Контроль & $23,9 \pm 0,72$ & $1,4 \pm 0,05$ & $29,0 \pm 1,06$ & $13,8 \pm 0,84$ \\
120 м & $22,1 \pm 0,92$ & $1,2 \pm 0,12$ & $28,1 \pm 0,92$ & $12,8 \pm 0,67$ \\
10 м & $20,6 \pm 0,70 *$ & $1,3 \pm 0,10$ & $25,0 \pm 0,87 *$ & $11,5 \pm 0,80$ \\
1,5 м & $17,2 \pm 0,68 *$ & $1,2 \pm 0,08$ & $22,1 \pm 1,23^{*}$ & $10,5 \pm 0,42^{*}$ \\
\hline
\end{tabular}

Примітки: * - різниця між контрольним і дослідним варіантами статистично достовірна за $\mathrm{P}<0,05 ; \mathrm{n}=30$.

Отже, вже на відстані 120 м від автошляху морфометричні параметри хвої та пагонів близькі до таких в умовно чистій зоні. Найсуттєвіше ці показники зменшуються у рослин, що зростають на розподільній смузі дороги (табл. 2, рис. 2). На відстані 10 м зберігається подібна закономірність стосовно майже всіх досліджуваних величин, але ступінь негативного впливу менша. Buharina and Povarnicina (2013) вказують на відносну стабільність морфометричних структур і високу життевість ялини колючої в умовах міського середовища м. Іжевськ. Згідно їх висновку, рослини цього виду внаслідок наявності товстої кутикули та шару віску стійкіші до забруднення атмосфери порівняно з ялиною звичайною. Виявлена певна чутливість морфометричних показників рослин на розподільній смузі та на відстані 10 м від автошляху може бути пояснена високою інтенсивністю руху автомобільного транспорту (близько 35 тисяч авто на добу при двобічному русі), а також іншими екологічними чинниками. Грунт на розподільній смузі засолений внаслідок зчищення на неї 3 проїжджої частини снігу та льоду, оброблених антифризами. Концентрації неорганічних аніонів і поліхлорованих фенолів внаслідок викидів дорожнім автотранспортом і зимового обслуговування значно зростають. Неорганічні аніони $\left(\mathrm{Cl}^{-}, \mathrm{NO}_{3}{ }^{-}, \mathrm{SO}_{4}{ }^{2-}\right)$, як результат викидів, осаджуються поблизу дороги (Hautala et al., 1995). Встановлено, що види роду Рісеа виявляють високу чутливість до засолення (Crosera et al., 2001; Kayama et al., 2003). Крім того, степова зона України характеризується малою кількістю опадів (близько 450 мм на рік) і низьким коефіцієнтом зволоження. Останніми роки спостерігається загальна аридизація клімату, що призводить до підвищення температури повітря, його сухості та низької вологості грунту (Izmenenie klimata ..., 2013). Ці чинники можуть посилювати вплив викидів автотранспорту на рослини. Тим паче, що на сухих грунтах у ялини колючої уповільнюється ріст (Buharina and Povarnicina, 2013). Вона може страждати також від повітряної посухи (Kuznecov, 2013).

Один з інформативних діагностичних показників стану фотосинтетичного апарату та адаптивних можливостей рослин вміст пластидних пігментів (Stirban et al., 1988, Verna and Singh, 2006). Використання таких показників, як ступінь зниження вмісту хлорофілу, різниця у змінах його форм $a$ i $b$, каротиноїдів дає можливість здійснювати не тільки біодіагностику стану рослин, а й окремих фітоценозів (Bessonova et al., 2004). Відмічається, що хлорофіл чутливіший до негативних чинників, ніж показники сирої маси та кількість листків (Dai Ling-Heng et al., 2009). Такі самі висновки в умовах дії стресових чинників роблять й інші автори (Yamasato et al., 2005; Tzanova and Uzunova, 2006).

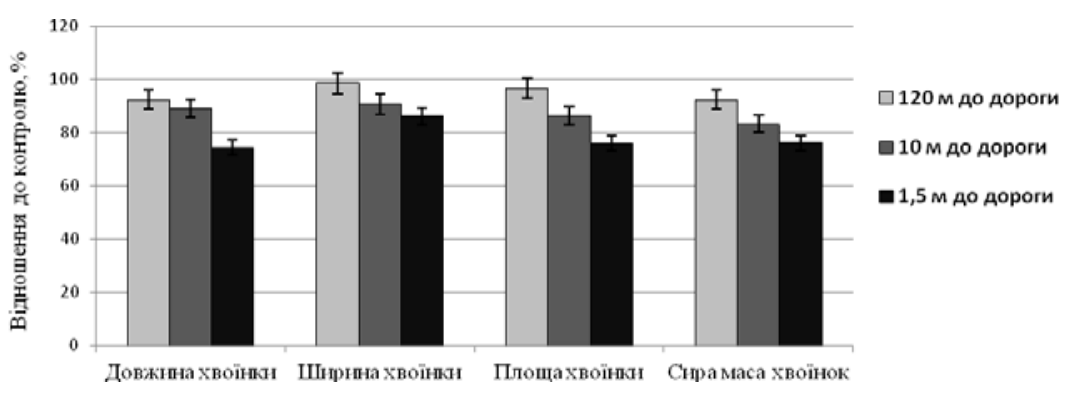

Рис. 2. Зменшення морфометричних показників та маси дворічної хвої ялини колючої при погіршенні умов зростання (\% до контролю)

Таблиця 3

Вплив віддалення від автошляху на вміст пігментів у хвої ялини колючої

\begin{tabular}{|c|c|c|c|c|c|c|c|}
\hline \multirow{2}{*}{ Місяць } & \multirow{2}{*}{ Контроль } & \multicolumn{6}{|c|}{ Відстань від автошляху } \\
\hline & & $120 \mathrm{M}$ & \% від контролю & $10 \mathrm{M}$ & \% від контролю & $1,5 \mathrm{M}$ & \% від контролю \\
\hline \multicolumn{8}{|c|}{ Сума хлорофілів $a+b$} \\
\hline Травень & $1,7 \pm 0,09$ & $1,8 \pm 0,09$ & 106,88 & $1,45 \pm 0,07$ & 85,29 & $1,20 \pm 0,09$ & 70,59 \\
\hline Червень & $1,6 \pm 0,07$ & $1,4 \pm 0,11$ & 91,08 & $1,25 \pm 0,07$ & 79,62 & $1,11 \pm 0,07$ & 70,70 \\
\hline Серпень & $1,4 \pm 0,10$ & $1,4 \pm 0,08$ & 94,41 & $1,13 \pm 0,06$ & 79,02 & $0,99 \pm 0,05$ & 69,23 \\
\hline Вересень & $1,7 \pm 0,11$ & $1,6 \pm 0,08$ & 96,43 & $1,37 \pm 0,08$ & 81,54 & $1,22 \pm 0,11$ & 72,62 \\
\hline \multicolumn{8}{|c|}{ Співвідношення хлорофілів $a$ i $b$} \\
\hline Травень & $1,8 \pm 0,11$ & $1,8 \pm 0,11$ & 96,72 & $1,6 \pm 0,08$ & 89,07 & $1,5 \pm 0,07$ & 81,97 \\
\hline Червень & $2,0 \pm 0,15$ & $1,7 \pm 0,08$ & 83,66 & $1,7 \pm 0,09$ & 81,68 & $1,6 \pm 0,09$ & 78,22 \\
\hline Серпень & $1,8 \pm 0,09$ & $1,7 \pm 0,07$ & 94,44 & $1,6 \pm 0,09$ & 90,00 & $1,5 \pm 0,07$ & 85,00 \\
\hline Вересень & $2,0 \pm 0,14$ & $1,7 \pm 0,09$ & 85,00 & $1,6 \pm 0,11$ & 81,50 & $1,5 \pm 0,10$ & 77,00 \\
\hline
\end{tabular}


Найвища кількість хлорофілу $a$ у хвої ялини колючої виявлена у травні, надалі вона знижується в літні місяці, а потім дещо зростає у вересні в усіх варіантах досліду. Подібна закономірність характерна і для змін вмісту хлорофілу $b$ (табл. 3, рис. 3, 4).

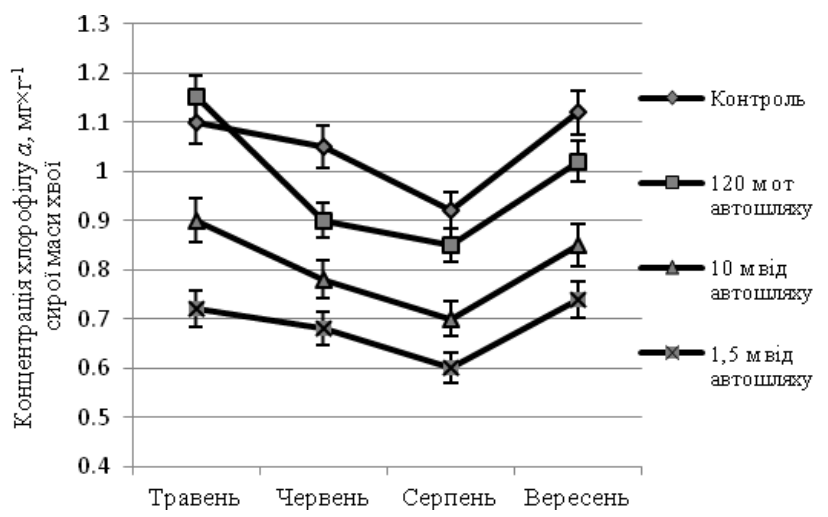

Рис. 3. Концентрація хлорофілу $а$ у хвої ялини колючої

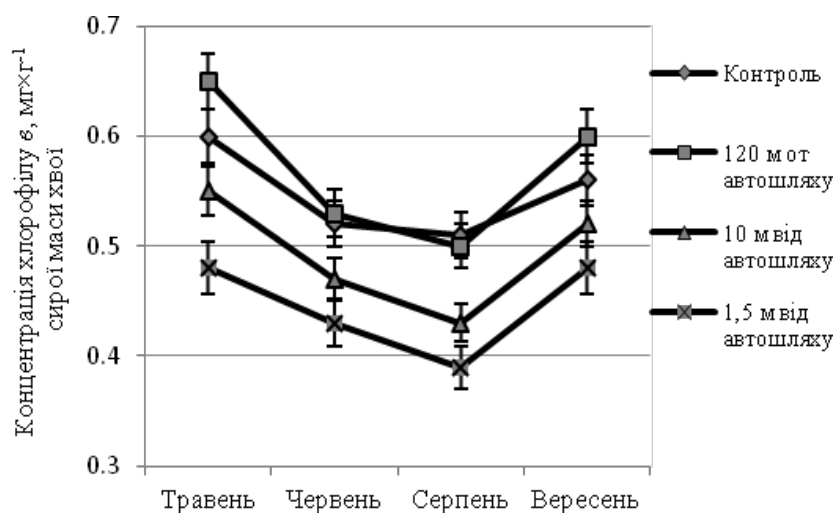

Рис. 4. Концентрація хлорофілу $b$ у хвої ялини колючої

Концентрація хлорофілу $a$ у хвоїнках дерев, що зростають на відстані 120 м від автошляху, майже така сама, як і у відносно чистій зоні. На відстані 10 м його вміст менший. В органах асиміляції рослин розподільної смуги автодороги кількість цієї форми зеленого пігменту зменшується суттєвіше, у середньому на $35 \%$ щодо контрольних значень. Виявлено, що в листках Ficus religiosa L. i Thevetia nerifolia (L.) Lippold, які зростають у зоні автомагістралей, що перехрещуються, з високим рівнем забруднення довкілля автотранспортними полютантами суттєво змінюється склад фотосинтетичних пігментів (Verna and Singh, 2006).

Вміст хлорофілу $b$, як і $a$, статистично не відрізняється у хвої дерев на дослідній ділянці 1 і в контролі. У рослин, що зростають на відстані 10 м від дороги, його концентрація також змінюється стосовно контролю, але у вересні різниця недостовірна. На розподільній смузі вміст хлорофілу в нижчий, ніж на інших ділянках.

Сума зелених пігментів $a+b$ однакова у хвої рослин контрольної ділянки та на відстані 120 м від автошляху. На дослідній ділянці 2 (10 м від автошляху) кількість хлорофілу $a+b$ у хвої дерев ялини менша, ніж у контролі і на ділянці 1. Залежно від місяця взяття проб різниця 3 контролем коливається від $14,7 \%$ до 21,0\%. Значне екологічне навантаження (ділянка 3) викликає суттєвіші зміни вмісту зелених пігментів у хвої. Частка хлорофілу $b$ зростає, про що свідчить зменшення відношення хлорофілів $a / b$. На більшу чутливість хлорофілу $a$ порівняно з хлорофілом $b$ до важких металів вказують Priseds'kij and Karas' (1991), Ol'hovich and Smirnova (1995). Bessonova et al. (2004) також встановили, що частка хлорофілу $b$ від загальної кількості хлорофілу в листках деревних рослин за умов забруднення довкілля полікомпонентними викидами автомобільного транспорту, як правило, зростає, що зумовлює зниження співвідношення $a / b$. На збільшення частки хлорофілу $b$ у листках стійких до викидів металургійного підприємства видів вказував також Tarabrin (1980). Підвищення вмісту хлорофілу $b$ за дії діоксиду азоту та співвідношення хлорофіл $a / b$ відмічала Bessonova (1992). Інші автори виявили агресивнішу дію токсикантів на хлорофіл $a$, ніж на хлорофіл $b$ (Ilkun, 1978; Farafontov, 1991; Tushilina et al., 1998). Така неоднозначність результатів може бути пов'язана зі впливом на рослини різних забруднювачів та їх сполучень. Синтез хлорофілу $b$, що відбувається за участю оксигензи хлорофілу $a$ - ключовий регуляторний етап у контролі за розміром фотосистеми I (Yamasato et al., 2005). Зміни співвідношення хлорофілів $a$ і $b$ за дії несприятливих екологічних чинників певною мірою відображують функціонування хлоропласта. Мала величина цього показника свідчить про найменший вміст хлорофілу на грану. Підвищення співвідношення зменшує ступінь агрегації тилакоїдів у мембранах хлоропласту (Kariya and Tsunoda, 1973), що впливає на інтенсивність фотосинтезу.

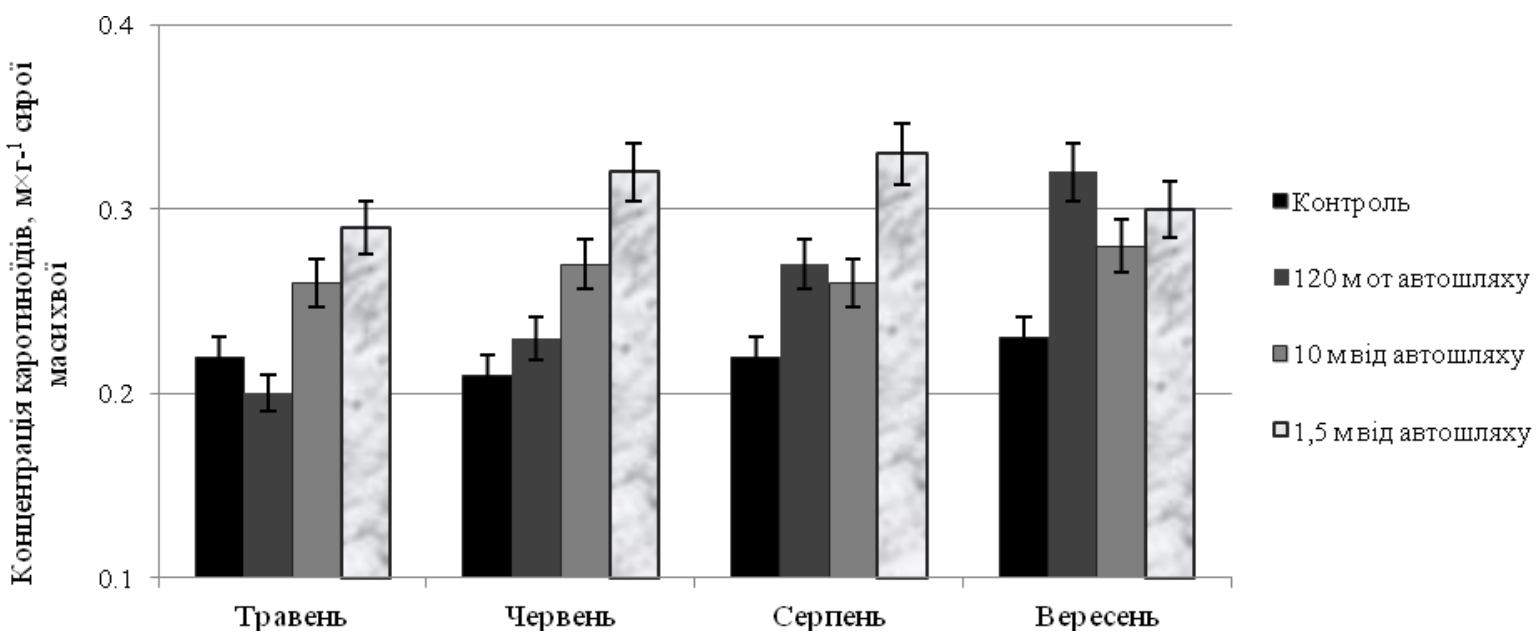

Рис. 5. Концентрація каротиноїдів у хвої ялини колючої

Співвідношення хлорофілів $a / b$ менше у хвої рослин, що зростають на відстані 10 м від автошляху $\mathrm{i}$, особливо, на його розподільній смузі. Характерно, що значення цього показника у досліджувані місяці майже не змінюється.
Вміст каротиноїдів у хвої ялини колючої також залежить від віддалення дерев відносно автошляху. Найнижчий він у рослин на відстані 120 м, а найвищий - в особин, що зростають у безпосередній близькості від нього. Концентрація жов- 
тих пігментів у хвої рослин ділянки 2 становить 118,2-128,7\% у різні строки дослідження відносно контролю, а на ділянці 3 130,4-150,0\% (рис. 5). Підвищення концентрації каротиноїдів у хвої ялини колючої як реакція на ріст у міському та промисловому середовищі також виявили Starikova et al. (2016).

Аналіз літературних даних свідчить, що активація каротиногенезу за дії помірних доз різних несприятливих екзогенних чинників довкілля - це захисно-пристосувальна реакція рослинного організму (Kushnirenko, 1975; Bessonova et al., 1976; Mihaylov et al., 1978). Каротиноїди, виконуючи роль додаткових пігментів, розширюють спектр поглинання, який використовують рослини для фотосинтезу. За надлишкової інтенсивності світла вони відіграють фотопротекторну роль (Kojama, 1991; Frank, 1999; Ralituho et al., 2007), дезактивують фотосенсибілізоване хлорофілом утворення реакційно-здатного синглетного кисню (Sietermann-Harms et al., 1980), гасять триплетний стан хлорофілу, виступають у ролі антиоксидантів (Krinsky, 1989), отже стабілізують мембрани хлоропластів (Havaux, 1998), беруть участь у захисті від пошкодження вільними радикалами, кількість яких зростає за несприятливих умов (Pinzeno et al., 1999).

Підвищення концентрації каротиноїдів у хвої рослин, що зростають на відстані $10 \mathrm{~m} \mathrm{i,} \mathrm{особливо,} \mathrm{на} \mathrm{розподільній} \mathrm{зоні}$ автошляху порівняно з контролем і ділянкою 1 можна розглядати як адаптивну реакцію, спрямовану на підтримання відносної стабільності фотосинтетичного апарату.

\section{Висновки}

Зростання дерев ялини колючої на розподільній смузі автошляху негативно впливає на річний приріст пагонів, морфометричні показники хвоїнок стосовно контролю, але їх кількість на 10 см пагона більша, ніж на інших ділянках. Величини більшості параметрів хвої у рослин, що ростуть на відстані 10 м від дороги, також менші, проте ступінь несприятливого впливу не така значна, як у рослин розподільної смуги. На відстані 120 м від дорожнього полотна відповідні показники практично не змінюються стосовно контролю.

В умовах суттєвішого забруднення довкілля полікомпонентними викидами автотранспорту (на відстані 1,5 і 10 м від автошляху) вміст хлорофілів $a$ і $b$ у хвої менший, каротиноїдів навпаки, більший. Концентрація пластидних пігментів на відстані 10 м від автошляху змінюються стосовно контролю, але значно менша, ніж на розподільній смузі. В умовах сильного стресу хвоя проявляє чутливість до негативних чинників, спричинених близьким розташуванням автошляху, але зі збільшенням відстані від магістралі цей вплив суттєво послаблюється.

\section{References}

Antipov, V. G. (2000). Dekorativnaja dendrologija [Decorative dendrology]. BGTU, Minsk (in Russian).

Bessonova, V. P. (2006). Praktikum z fiziologiyi roslin [Workshop on Plant Physiology]. DDAU, Dnipropetrovsk (in Ukrainian).

Bessonova, V. P., Kapelyush, N. V., Ovcharenko, S. V., \& Pismenchuk, V.D. (2004). Vlijanie polikomponentnyh vybrosov avtomobil'nogo transporta na soderzhanie hlorofilla v list'jah drevesnyh rastenij [Influence of multicomponent emissions of road transport on the content of chlorophyll in leaves of woody plants]. Bjulleten' Nikitskogo Botanicheskogo Sada, 89, 73-75 (in Russian).

Bessonova, V. P. (1992). Vpliv vazhkih metaliv na pigmentnu sistemu listka [The impact of heavy metals on a leaf pigment system]. Ukrainskij Botanicheskij Zhumal, 49, 63-66 (in Ukrainian).

Bessonova, V. P., Mihaylov, O. F., \& Koryitova, A. I. (1976). Dinamika pigmentov i uglevodov v listjah akacii beloj, proizrastajushhej v razlichnyh lesorastitel'nyh uslovijah [Dynamics of pigments and carbohydrates in leaves of acacia white, growing in various forest conditions]. Voprosy Stepnogo Lesovedenija i Ohrany Prirody, 3, 100-105 (in Russian).

Brygadyrenko, V. V. (2014). Influence of soil moisture on litter invertebrate community structure of pine forests of the steppe zone of Ukraine. Folia Oecologica, 41(1), 8-16.
Brygadyrenko, V. V. (2016). Effect of canopy density on litter invertebrate community structure in pine forests. Ekológia (Bratislava), 35(1), 90-102.

Buharina, I. L., \& Pashkova, A. S. (2015). Osobennosti fotosinteticheskogo apparata eli koljuchej (Picea pungens) i eli evropejskoj (Picea pungens) $\mathrm{v}$ uslovijah gorodskoj sredy [Features of photosynthetic apparatus of Picea pungens and Picea abies in an urban environment]. Sovremennye Problemy Nauki i Obrazovanija, 3, 1-8 (in Russian).

Buharina, I. L., \& Povarnitsina, T. M. (2013). Ekologo-biologicheskaja harakteristika Picea pungens (Pinaceae) v uslovijah gorodskoj sredy [Ecological and biological characteristics of Picea pungens (Pinaceae) in an urban environment]. Rastitel'nye Resursy, 49, 312-318 (in Russian).

Bukharina, I. L., Vedernikov, K. E., \& Pashkova, A. S. (2016). Morphophysiologic traits of spruce trees in conditions of Izhevsk. Contemporary Problems of Ecology, 9, 853-862.

Crosera, C., Renaultb, S., Franklina, J., \& Zwiazeka, J. (2001). The effect of salinity on the emergence and seedling growth of Picea mariana, Picea glauca, and Pinus banksiana. Environmental Pollution, 115, 9-16.

Farafontov, M. G. (1991). Bioindikatornye svojstva hlorofilla v uslovijah vozdejstvija zagrjaznenij neopredelennogo sostava [Bioindicative properties of chlorophyll in the effects of pollution of an undefined composition]. Jekologija, 5, 76-79 (in Russian).

Frank, H. A. (1999). Incorporation of carotenoids into reaction center and light-harvesting pigment-protein complexes. The Photochemistry of Carotenoids. Advances in Photosynthesis and Respiration, 8, 235-244.

Getko, N. V. (1989). Rastenija v tehnogennoj srede [Plants in the technogenic environment]. Nauka i Tehnika, Minsk (in Russian).

Golovach, O. M., \& Demkov, O. G. (2006). Vlijanie svinca na rost i soderzhanie fotosinteticheskih pigmentov i aktivnost' karboangidrazy u prorostkov kukuruzy [The influence of lead on growth, the content of photosynthetic pigments and the activity of carbonic anhydrase in maize seedling]. Fiziologiya i Biohimiya Kulturnih Rasteniy, 38, 353-358 (in Russian).

Hautala, E.-L., Rekilä, R., Tarhanen, J., \& Ruuskanen, J. (1995). Deposition of motor vehicle emissions and winter maintenance along roadside assessed by snow analyses. Environmental Pollution, 87, 45-49.

Havaux, M. (1998). Carotenoids as membrane stabilizers in chloroplasts. Plant Science Journal, 3, 147-151.

Izmenenie klimata. Fizicheskaja nauchnaja osnova. Rezjume dlja politikov. Doklad rabochej gruppy I (2013) [Climate change. Physical scientific basis. Summary for politicians.]. Elektronnyiy Resurs (in Russian).

Ilkun, G. M. (1978). Zagrjazniteli atmosfery i rastenija [Pollutants of the atmosphere and plants]. Naukova Dumka, Kiev (in Russian).

Kayamaa, M, Quoreshia, A. M., Kitaokab, S., Kitahashib, Y., Sakamotoc, Y., Maruyamac, Y., Kitaoc, M., \& Koike, T. (2003). Effects of deicing salt on the vitality and health of two spruce species, Picea abies Karst., and Picea glehnii Masters planted along roadsides in northern Japan. Environmental Pollution, 124, 127-137.

Karija, K., \& Tsunoda, S. (1973). Chloroplast characters and the photosynthetic rate of cultivated Brassica species. Tohoku Journal of Agricultural Research, 24(1), 1-13.

Kleyn, R. M., \& Kleyn, D. T. (1974). Metody issledovanija rastenij [Methods for plants studying]. Kolos, Moscow (in Russian).

Kojama, J. (1991). Structure and functions of carotenoids in photosynthetic systems. Journal Photochemistry Photobiology, 9, 265-280.

Kolesnikov, A. I. (1974). Dekorativnye formy drevesnyh porod [Decorative forms of tree species]. Lesnaja Promyshlennost', Moscow (in Russian).

Krinsky, N. J. (1989). Antioxidant function of carotenoids. Free Radical in Biology and Medicine, 7, 617-635.

Kushnirenko, M. D. (1975). Fiziologiya vodoobmena i zasuhoustoychivosti plodovih rasteniy [Physiology of water exchange and drought resistance of fruit plants]. Shtiinitsa, Kishinev (in Russian).

Lawlor, D. W., \& Tezara, W. (2009). Causes decreased photosynthetic rate and metabolic capacity in water-deficient leaf cells: A critical evaluation of mechanisms and integration of processes. Annals of Botany, 103, 561-579.

Mihaylov, O. F., Bessonova, V. P., \& Koryitova, A. I. (1978). Vliyanije kinetina i rentgenovskogo obluchenija na rostovyije rostovye processy i nakoplenie pigmentov v prorostkah goroha [Effect of kinetin and X-ray irradiation on growth processes and accumulation of pigments in pea seedlings]. Fiziologija i Biohimija Kul'turnyh Rastenij, 10(1), 70-76 (in Russian).

Nikolaevskij, V. S. (1979). Biologicheskie osnovy gazoustojchivosti rastenij [Biological basis of gas resistance of plants]. Nauka, Novosibirsk (in Russian).

Olhovich, O. P., \& Smimova, N. G. (1995). Soderzhanie pigmentov v vysshih vodnyh rastenijah pod vlijaniem tjazhelyh metallov [The content of pigments in higher water plants under the influence of heavy metals]. Ukrainskij Botanicheskij Zhurnal, 53, 213-219 (in Russian).

Pinzeno, C., Nanni, B., \& Zandomeneglhi, M. (1999). Aging free radical and antioxidants in wheat seeds. Journal of Agricultural and Food Chemistry 47(4), 1333-1339. 
Prisedskiy, Y. G., \& Karas, S. A. (1991). Vliyanie zagryazneniya pochvyi kadmiem na rostovyie protsessyi prorostkov drevesnyih i kustarnikovyih rasteniy [Effect of cadmium soil pollution on the growth processes of sprouts of trees and shrubs]. Donetskiy Universitet, Donetsk, 80-88 (in Russian).

Ralituho, L., Rech, J., \& Jahnus, P. (2007). Specific xantophylls in light. Planta, 227, 423-429.

Sergeychik, S. A. (1997). Rasteniya i ekologiya [Plants and ecology]. Urozhay, Minsk (in Russian).

Sietermann-Harms, D., Mazliak, E. P., \& Benvenist, P. C. (1980). Costes The role of carotenoids in chloroplasts of higher plants. Biogenesis and function of plants lipid. Elsevier, North Holland Biomed Press, Amsterdam, New York, Oxford. Pp. 331-340.

Starikova, E. A., Voskresenskaja, O. L., \& Sarbaeva, E. V. (2016). Izmenenie pigmentnogo kompleksa eli koljuchej v uslovijah gorodskoj sredy [Change of a pigmentary complex of a fir-tree prickly in the conditions of the urban environment]. Mezhdunarodnyj Nauchno-Issledovatel'skij Zhurnal, 10(52), 46-48 (in Russian).

Stirban, M., Bathory, D., Fabian, A., \& Sparchez, C. (1988). Adaptive of significance of contents in photoassimilatory pigments and SH-groups of tree leaves from ecosystems polluted with $\mathrm{SO}_{2}$ and heavy metals. Evolution and Adaptation, 3, 195-200.

Tarabrin, V. P. (1980). Ustojchivost' rastenij k promyshlennomu zagrjazneniju okruzhajushhej sredy [Stability of plants to industrial pollution of the environment]. Promyishlennaya Botanika, 52-108 (in Russian).

Tushilina, V. V., Ladanova, N. V., \& Plyuskina, S. N. (1998). Vlijanie tehnogennogo zagrjaznenija na fotosinteticheskij apparat sosny [Influence of technogenic pollution on photosynthetic pine plant]. Ekologija, 2, 89-93 (in Russian).

Tzanova, A., \& Uzunova, A. (2006). Intaraction between cadmium and pataquat stress on Pisum sativum. Photosyntetic response to pea plants induced by $\mathrm{Cd}^{2+}$ and paraquat. Reports of the Bulgarian Academy of Sciences, 59(6), 651-656.

Verna, A., \& Singh, S. N. (2006). Biochemical and ultrastructure changes in plant foliage exposed to auto-pollution Environmental Monitoring and Assessment, 120, 585-602.

Wannaz, E. D., Zugaldo, V. A., \& Pignata, M. L. (2003). Air pollution effect on monoterpens composition and foliar parameters in Schinus ariara L. Science of the Total Environment, 305, 177-193. 